\title{
Comparative maturation schedules of two Columbia River sockeye salmon Oncorhynchus nerka populations
}

\author{
Neala W. Kendall ${ }^{1, *}$, Andrew H. Dittman ${ }^{2}$, Thomas P. Quinn ${ }^{1}$ \\ ${ }^{1}$ School of Aquatic and Fishery Sciences, University of Washington, Seattle, Washingon 98195, USA \\ ${ }^{2}$ Northwest Fisheries Science Center, NOAA-Fisheries, Seattle, Washingon 98112, USA
}

\begin{abstract}
Age and size at maturation affect an individual's reproductive success and reflect both evolutionary adaptations and phenotypic responses to environmental conditions. We evaluated age and size at maturity of sockeye salmon Oncorhynchus nerka from 2 populations within the Columbia River drainage: the Okanagan River, British Columbia (Canada), population and the endangered population from Redfish Lake, Idaho, USA. We compared available data on wild fish to data on fish reared under controlled laboratory conditions. Data obtained from the wild revealed that Okanagan River fish smolted at younger ages and larger sizes and then matured at younger ages than Redfish Lake fish. In captivity, fish from both populations were grown at the same rate and all smolted at Age 1. Despite their similar lengths as smolts, a greater proportion of Redfish Lake $(>90 \%)$ than Okanagan River sockeye salmon (68\%) matured 1 yr after smolt transformation. Calculated probabilistic maturation reaction norm midpoints for the captive fish indicated that Redfish Lake sockeye salmon in this study may have lower maturation thresholds than Okanagan River fish. Expression of different life history traits in the 2 populations under controlled conditions is consistent with a genetic basis for these traits and countergradient variation in maturation thresholds. Understanding life history differences and local adaptation among populations is important for their conservation, including anticipating responses to captive breeding regimes and supplementation, changing environmental conditions, and selective harvest.
\end{abstract}

KEY WORDS: Sockeye salmon · Age and size maturation · Smolt transformation · Local adaptation · Maturation threshold $\cdot$ Countergradient variation $\cdot$ Columbia River

\section{INTRODUCTION}

Growth, maturation, reproduction, survival, and mortality are essential processes in the life cycles of all animals, and life history traits associated with these processes characterize populations within species. Environmental conditions, evolutionary pressures, and contemporary selection regimes experienced by individuals in different populations often result in varying life history patterns. The separate and combined influences of environmental conditions and genetic control on a population's life history traits result in local adaptation and have strong implica- tions for its conservation and management (Taylor 1991). Populations should be managed in ways that recognize and sustain their diverse traits (Wood 1995), and successful restoration and enhancement programs need to consider adapted characteristics (Taylor 1991). Life history diversity, especially in growth and age at maturity, buffers populations and groups of populations from environmental variability and increases their productivity (Koellner \& Schmitz 2006, Greene et al. 2010, Schindler et al. 2010). Thus, maintaining productivity may be best achieved by conserving as many locally adapted populations as possible (Wood 1995). Identification of life history dif- 
ferences among populations and understanding how they are shaped, including interactions between genotypic and environmental factors, is critical to population conservation (Waples et al. 2001).

Populations may vary in growth and age and size at maturity as a direct consequence of environmental differences. They may also evolve genetic differences in growth rate and the relationship between growth and maturation that are adaptations to their environment. Environmental and genetic influences can be additive (genetic tendency to grow rapidly in a population whose environment facilitates rapid growth), and in other cases these tendencies are opposite, resulting in diminished phenotypic variation - a process known as countergradient variation (Conover \& Schultz 1995). For example, individuals in a cool environment may grow more slowly than those from a population experiencing warmer water. However, when both groups are raised in a common, warm environment, individuals adapted to the cooler environment may grow faster than those adapted to the warmer environment if they have an inherently greater capacity for growth and are only limited by temperature. Countergradient variation in growth (Conover \& Present 1990, Conover et al. 1997, Arendt \& Wilson 1999) and other traits including body size and shape (Marcil et al. 2006), developmental rate (Laugen et al. 2003), and coloration (Craig \& Foote 2001, Grether et al. 2005) have been reported in many fish species. For example, Craig \& Foote (2001) found that kokanee salmon (landlocked sockeye salmon Oncorhynchus nerka) and anadromous sockeye salmon both display similar shades of red in their respective natal environments. However, when they are exposed to low-carotenoid diets under laboratory conditions, kokanee sequester carotenoids to the flesh musculature 3 times more efficiently than sockeye and thus appear redder in color, indicating a genetic compensation for the more limited carotenoids in lakes compared to marine waters. Examination of such countergradient variation can help to understand variability in life history traits among individuals from different populations, can contribute to effective management of these populations, such as through effective stocking and introduction (Conover \& Schultz 1995), and can help anticipate their responses to changes in the environment and in selection regimes.

Size and age at maturation are especially well-studied life history traits in salmonid fishes. These species home to natal sites for breeding, resulting in reproductive isolation, complex population structure, and adaptations to the environmental conditions of the natal site (Ricker 1972, Taylor 1991, Wood 1995, Garcia de Leaniz et al. 2007). Life history diversity in salmon populations can both increase productivity and buffer size fluctuations (Greene et al. 2010, Schindler et al. 2010). However, altered selection regimes through fishing (Kendall et al. 2009), artificial propagation (McLean et al. 2005), and environmental change (Holtby 1988, Pyper et al. 1999, Beechie et al. 2006) can affect age and size at maturation of salmonids, with implications for their conservation. For example, reduction of the number of age classes in exploited fish stocks can result in decreased reproductive rates and stock productivity (Hsieh et al. 2006, Venturelli et al. 2009), and hatchery supplementation programs can limit life history diversity expressed in the stocked populations (Ayllon et al. 2006).

In natural salmonid populations, age and size at maturation patterns reflect both environmental and genetic influences. Environmental conditions can affect smolt size (Thorpe 1986, Randall et al. 1987), which in turn influences age and size at maturation (Randall et al. 1986, Thorpe 1987, Hutchings \& Jones 1998). Genetic factors also affect age and size at maturity (Ricker 1972, Hard 2004, Carlson \& Seamons 2008); offspring age at maturity is often linked to that of their parents (Tipping 1991, Hankin et al. 1993). It can be difficult to determine if both genetic and environmental factors influence population-level life history variation from sampling in the field (Beacham \& Murray 1987, Roni \& Quinn 1995) because of the interplay between these factors, and thus experiments can yield important insights.

In the present study, we examined age and size at smolt transformation maturity of sockeye salmon in 2 populations using data collected from fish in the wild and in a controlled laboratory experiment. The populations originated in the Okanagan River of British Columbia, Canada, which has been labeled a stock of special concern, and Redfish Lake, in the Stanley Basin, Idaho, USA, where the stock was listed as endangered in 1991 under the US Endangered Species Act (status of both populations given by Gustafson et al. 1997). These populations spawn in distant parts of the Columbia River system (Fig. 1), so have been subjected to different environmental conditions and regimes of selection. In contrast to the healthy populations in the northern end of their range where there are abundant long-term data on life history patterns (e.g. Bristol Bay, Alaska; Quinn et al. 2009), these depleted populations are operating under extreme conditions for the species, and data on their life history patterns are sparse. Their critical status is likely to be exacerbated by changing climate conditions (Crozier et al. 2008).

We first summarize historical and recent data on life history transitions (size and age at smolt transformation and maturation) of fish spawning in the wild to understand life history variation between the populations. We then report data on fish from each pop- 


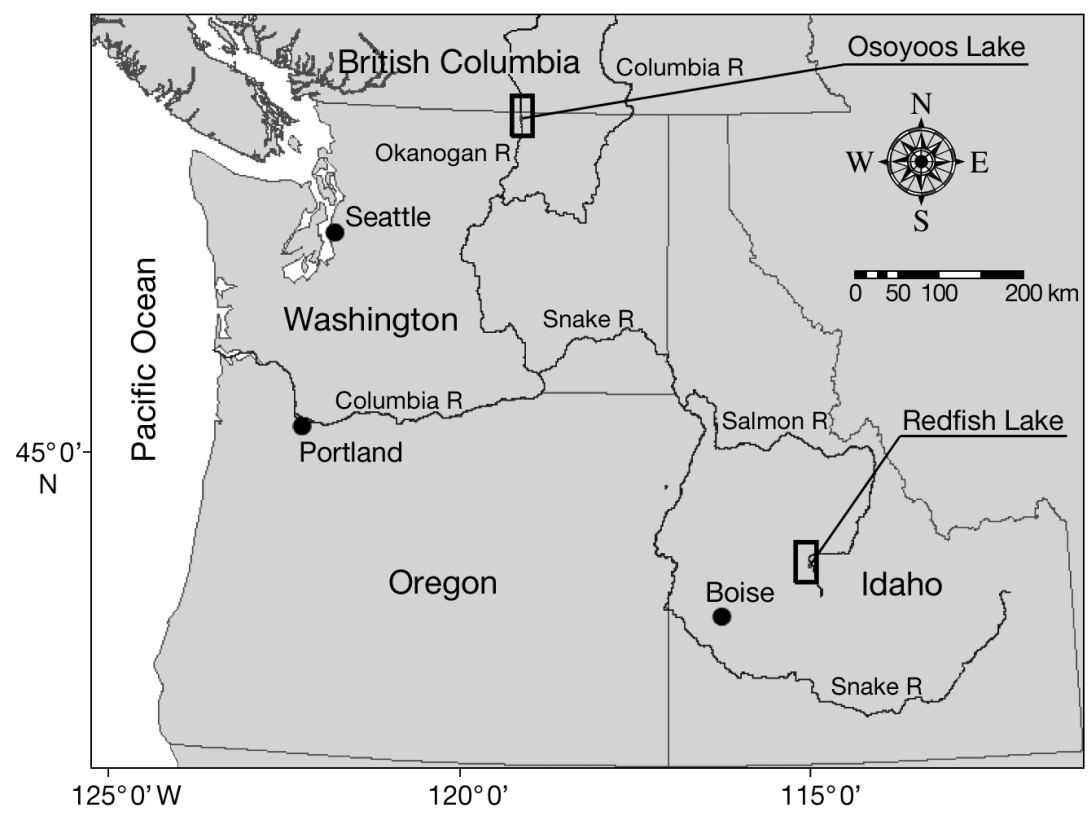

Fig. 1. Locations of the spawning and rearing sites of the 2 sockeye salmon populations under study: Okanagan River and Osoyoos Lake, British Columbia, Canada, and Redfish Lake, Idaho, USA

\section{MATERIALS AND METHODS}

Study sites. Redfish Lake is at $1996 \mathrm{~m}$ elevation and is $1444 \mathrm{~km}$ from the Pacific Ocean via the Columbia, Snake, and Salmon Rivers (Bjornn et al. 1968; Fig. 1). The Okanagan River and Osoyoos Lake, where Okanagan River sockeye salmon spawn and then rear as juveniles, respectively, are at $278 \mathrm{~m}$ elevation and are $986 \mathrm{~km}$ from the Pacific Ocean via the Columbia River (Burgner 1991; Fig. 1). Consistent with the higher elevation, Redfish Lake is cooler, with monthly average lake surface water temperatures ranging from $0.3^{\circ} \mathrm{C}$ in February to $17.9^{\circ} \mathrm{C}$ in July (1996 to 2008 ; R. Griswold, Biolines Environmental Consulting, unpubl. data), compared to $2.2^{\circ} \mathrm{C}$ in February to $22.3^{\circ} \mathrm{C}$ in July for Osoyoos Lake (2002 to 2005; M. Stockwell, Department of Fisheries and Oceans Canada (DFO) unpubl. data). At 25 to $35 \mathrm{~m}$ depth, where sockeye salmon are likely to rear, Osoyoos Lake has aver-

ulation spawned and reared under controlled laboratory conditions. The laboratory study was designed for another purpose (specifically, to study olfactory imprinting; Dittman et al. 2009), but the data provide a rare opportunity to shed light on the genetic and environmental influences on maturation in these fish. We tested the null hypothesis that age and size at maturation would be similar between the populations in captivity because their juvenile growth rate, smolt size, and post-smolt environment were similar, against 2 predicted alternative hypotheses: (1) age and size at maturity patterns observed in wild fish would be mirrored in the laboratory due to genetic controls over these traits; or (2) the patterns observed in wild fish would be less divergent, or even reversed, in the laboratory due to environmental influences interacting with genetic control, such as countergradient variation in growth rate and/or maturation. To test these hypotheses, we compared average age and size at smolt transformation and at maturity between the populations and calculated probabilistic maturation reaction norms (PMRNs) for the experimental fish, giving another perspective on age and size at maturation differences. PMRNs describe the probability of an individual maturing at a given time as a function of age and body size (Heino et al. 2002). Differences in age and size at maturation between the populations in both wild and captive settings would be consistent with the presence of local adaptations in these populations. aged $7.8^{\circ} \mathrm{C}$ across all months from 1971 to 2000 (M. Stockwell, DFO unpubl. data) compared to $4.8^{\circ} \mathrm{C}$ in Redfish Lake from all months from 1996 to 2008 (R. Griswold, Biolines Environmental Consulting, unpubl. data).

Review of historical and recent data on life history transitions. Historical and recent data on wild sockeye salmon of the Okanagan River and Redfish Lake populations, including smolt and adult age and size, were compiled from a combination of peer-reviewed literature, agency reports, and personal communications. To collect these data, we searched the Web of Science for published data, spoke with scientists and managers studying and working with these fish, and searched agency websites, including Bonneville Power Administration, Idaho Department of Fish and Game (IDFG), Columbia River Inter-tribal Fisheries Commission, and $\mathrm{DFO}$, to find publications, reports, and unpublished data. Detailed information about the historical and recent data on life history transitions included in this paper is available in Table $\mathrm{S} 1$ in the supplement at www.int-res.com/articles/suppl/n013p051_supp.pdf.

Currently, Redfish Lake sockeye salmon are intensively managed due to their endangered status. In recent years, many Redfish Lake sockeye salmon have been spawned and reared as juveniles in captivity and released into Redfish Lake at various developmental stages. We did not use data from these fish in our analysis, though some of the naturally spawning fish contributing to the datasets may have been their offspring. Although the paucity of data from overlapping years 
when the fish were abundant and largely wild limited direct annual comparisons of age and size of smolts and adults from the 2 populations, we analyzed all data available to characterize life history patterns of these 2 populations as naturally reproducing entities. Specifically, we compared qualitatively or quantitatively, using $t$-tests or Mann-Whitney-Wilcoxon (MWW) tests (when data were not normally distributed), differences in age and size at smolt and maturation transitions.

Laboratory experiment. Captive sockeye salmon from both populations were reared from embryo to adulthood at the University of Washington's Big Beef Creek research station, which is on a tributary of Hood Canal in western Washington, USA. The project began in fall 2004 with the establishment of the 2 populations: Okanagan River sockeye salmon were first filial generation (F1) offspring of captive-reared fish originally obtained from the Colville Tribe's Cassimer Bar Salmon Hatchery, and Redfish Lake fish were the 4th generation of fish captively reared in the National Marine Fisheries Service captive broodstock program at Burley Creek, Washington. The Okanagan River sockeye salmon were the offspring of 2 Age 4 females crossed with 4 Age 4 males, and the Redfish Lake fish were the offspring of an Age3 female crossed with 2 Age 3 males. A larger and more diverse set of sires and dams would have been desirable, but the status of populations did not permit this.

Eyed eggs from both populations were transferred to the Big Beef Creek field station in December 2004 and reared in constant $10^{\circ} \mathrm{C}$ well water throughout their lives. Okanagan River fry $(\mathrm{n}=1159)$ were reared in 6 different tanks, and the Redfish Lake fry $(n=843)$ were reared in 4 tanks. All fish were fed the same food. From fry to smolt stage, their rations were adjusted after periodic weighing and measuring events to keep all fish at the same length and target mass ( $30 \mathrm{~g})$ by June 2006 , by which time they were expected to have completed the smolt transformation process. To assess smolting, 50 to 80 fish were sacrificed; this process was repeated approximately every $3 \mathrm{wk}$, and a total of 7 times between February and June of 2006, measured for length and weight, and gill samples were collected for later gill ATPase measurements. Filaments from 3 gill arches were placed in a solution of sucrose, EDTA, and imidazole according to methods described by Zaugg (1982) and then frozen on dry ice and stored at $-80^{\circ} \mathrm{C}$. Gill $\mathrm{Na}+, \mathrm{K}+$-ATPase activities were measured using the method of McCormick (1993).

In July 2006, after smolt transformation, all fish were fin clipped to identify their tank grouping, and were then transferred to 3 circular ( $4.1 \mathrm{~m}$ diameter) outdoor freshwater tanks where they were raised communally to maturity on an ad libitum diet. On 9 dates between March and November 2007, 8 to 135 fish from each population were sacrificed, measured for length, weighed, and plasma and gonads were collected to determine maturation (i.e. at Age 3; Dittman et al. 2009). Maturation status for females was established by weighing total body weight and gonads of all fish and calculating the gonadosomatic index (GSI) as (gonad weight/body weight) $\times 100$. All female fish with a GSI $>0.5$ were considered to be maturing. Maturation status for males was established by determining the plasma 11-ketotestosterone concentrations for each fish as described by Larsen et al. (2004). Fish from both populations were represented during each sampling. Fewer fish were sampled on the first 2 dates, in March and May ( $\mathrm{n}=64$ of the 2040 fish in the olfaction study), than on the later dates (June through November). On these earliest 2 dates, the status of maturing fish was clear $(n=38)$, but if a fish had not yet begun the process of maturation it was unclear whether it would or would not have matured later that year. Therefore, these fish were not included in our study. By June it was very evident whether a fish would or would not mature that year, so both immature and maturing fish could be distinguished and were included in our study. The experiment was terminated in November 2007, and it was assumed that all fish that had not matured would have done so in the following year, at Age 4. This assumption was supported by data from other Redfish Lake sockeye salmon reared in fresh water, under similar conditions and temperatures as those in our study, showing that $>99.9 \%$ of the fish matured as 3- or 4-yr-olds (Redfish Lake sockeye salmon captive broodstock program; Frost et al. 2008).

For our analyses, including the PMRN calculation, it was necessary to use lengths of all experimentally reared smolts and immature/maturing adults at a common date (June 2006 for smolts and November 2007 for adults). To calculate these, we modeled juvenile growth (length averaged for all fish sampled each month) using exponential functions and post-smolt growth (again, length averaged for all fish sampled each month) using logarithmic functions. Except for Okanagan River immature length, all model fits had $\mathrm{R}^{2}$ values $>0.9$ (Fig. 2). The length of each individual smolt and immature/maturing adult was then extrapolated to the common date (June for smolts and November for adults) using the regression equations as follows: smolts in June 2006, Okanagan: $y=101.81 e^{0.061 x}, R^{2}=0.97$; Redfish Lake: $y=$ $102.02 \mathrm{e}^{0.06 x}, \mathrm{R}^{2}=0.96$. Fish in November 2007, Okanagan maturing: $y=83.2 \ln (x)+258.56, \mathrm{R}^{2}=0.94$, immature: $y=43.04 \ln (x)+295.91, \mathrm{R}^{2}=0.36$; Redfish Lake maturing: $y=89.9 \ln (x)+243.93, \mathrm{R}^{2}=0.92$, immature: $y$ $\left.=89.59 \ln (x)+206.16, \mathrm{R}^{2}=0.95\right)$ (Fig. 2).

We calculated a PMRN midpoint (specifically, the length at which the probability of maturing was $50 \%$; $L_{\mathrm{p} 50}$ ) for immature/maturing fish from each captive population, based on the environmental conditions to 


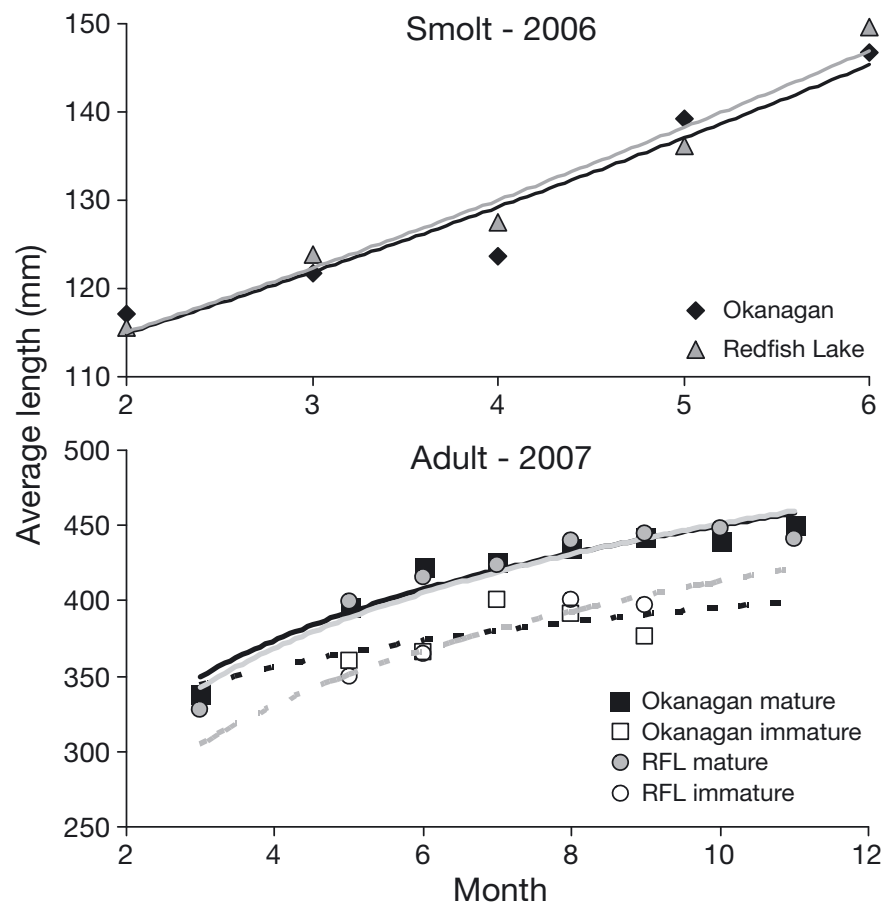

Fig. 2. Oncorhynchus nerka. Average length of captivereared Okanagan River and Redfish Lake (RFL) sockeye salmon sampled between February and June 2006 (smolts) and between March and November 2007 (adults). Fitted regression lines (black: Okanagan; grey: RFL) using exponential functions were used to predict length of smolts in June 2006. For adults, fitted regression lines using logarithmic functions were used to predict length of fish in November 2007 (see 'Materials and methods' for details)

which the fish were exposed, to further understand life history divergence. Though less accurate than calculation of full PMRNs based on a wider range of growth trajectories and environmental conditions (Dieckmann \& Heino 2007), these midpoints provide a useful index of the relationship between length and maturation probability. We combined data from males and females for each population because maturation status and body size were similar between sexes. The probability of maturing $(m)$ increased with fish length $(L)$ from 0 (immature) to 1 (mature) in a sigmoid shape, suggesting the use of the logistic function. We estimated the $L_{\mathrm{p} 50}$ for each population by fitting a logistic regression (glm with a logit link function) with $m(L)$ as the response and $L$ as the predictor. $L_{\mathrm{p} 50}$ values were calculated by dividing the negative intercept by the slope of the logistic regressions (Eqs. 1 \& 2):

$$
\begin{gathered}
\log \operatorname{it}(m(L))=\log _{\mathrm{e}}\{m(L) /[1-m(L)]\}=\beta_{0}+\beta_{1} \times L \\
L_{\mathrm{p} 50}=-\frac{\beta_{0}}{\beta_{1}}
\end{gathered}
$$

We used likelihood ratio tests to assess significant differences in maturation thresholds ( $L_{\mathrm{p} 50}$ values) between the 2 populations. To do this, we calculated the likelihood of maturation, with the same parameters for all fish and with separate parameters for each population, using the logistic likelihood function with a binomial error distribution.

\section{RESULTS}

\section{Historical and recent data on life history transitions}

Smolt age and size

Most wild Okanagan River sockeye salmon smolts were Age 1, presumably because their rearing lake, Osoyoos Lake, is warm, shallow, and eutrophic (data from sources 2, 4, 19, 23, 34, and 35 in Table S1 in the supplement). Between 1946 and 1953, $93 \%$ of smolts were yearlings, as were $86 \%$ of those between 1986 and 1993. Few Okanagan River fish rear in freshwater for $2 \mathrm{yr}$, and almost none migrate to the ocean as subyearlings. On the other hand, Redfish Lake sockeye salmon smolts have historically been Age 1 or 2, depending on their length at the end of their first year in fresh water. When the average fork length was $<80$ $\mathrm{mm},<50 \%$ of smolts left the lake as yearlings, whereas when the fork length was $\sim 100 \mathrm{~mm},>90 \%$ of smolts left the lake as yearlings (Bjornn et al. 1968). Thus, wild Okanagan River sockeye salmon smolts have tended to be younger than Redfish Lake smolts.

The mean \pm SD length of wild Okanagan River sockeye smolts from 12 yr between 1957 and 2005 was $107.8 \pm 13.7 \mathrm{~mm}$ (range of annual means = 86-131 mm; data from sources 4, 23, 34, and 35 in Table S1; Fig. 3A) whereas for 22 yr between 1956 and 2007, the average length of wild Age 1 smolts from Redfish Lake was $97.8 \pm 14.1 \mathrm{~mm}$ (range = 67-117 mm; data from sources 3, 20-22, 24-29, and 31-33 in Table S1; Fig. $3 \mathrm{~A}_{;} t=1.96, \mathrm{df}=32, \mathrm{p}=0.03$ for a 1-tailed 2-sample $t$-test of the annual means assuming that Okanagan River fish were larger given their warm and productive rearing lake). Compared to other North American sockeye salmon populations for length at age 1, Okanagan River smolts are in the 93rd percentile and Redfish Lake smolts are in the 84th percentile (Fig. 3B).

\section{Age and size at maturation}

In most years, the majority of wild Okanagan River fish matured 2 yr after their smolt transformation, but in some years more fish matured after only $1 \mathrm{yr}$ in the ocean rather than 2 (Table 1 ; data from sources 1 , 4-18, 30, and 36 in Table S1). On the other hand, most 


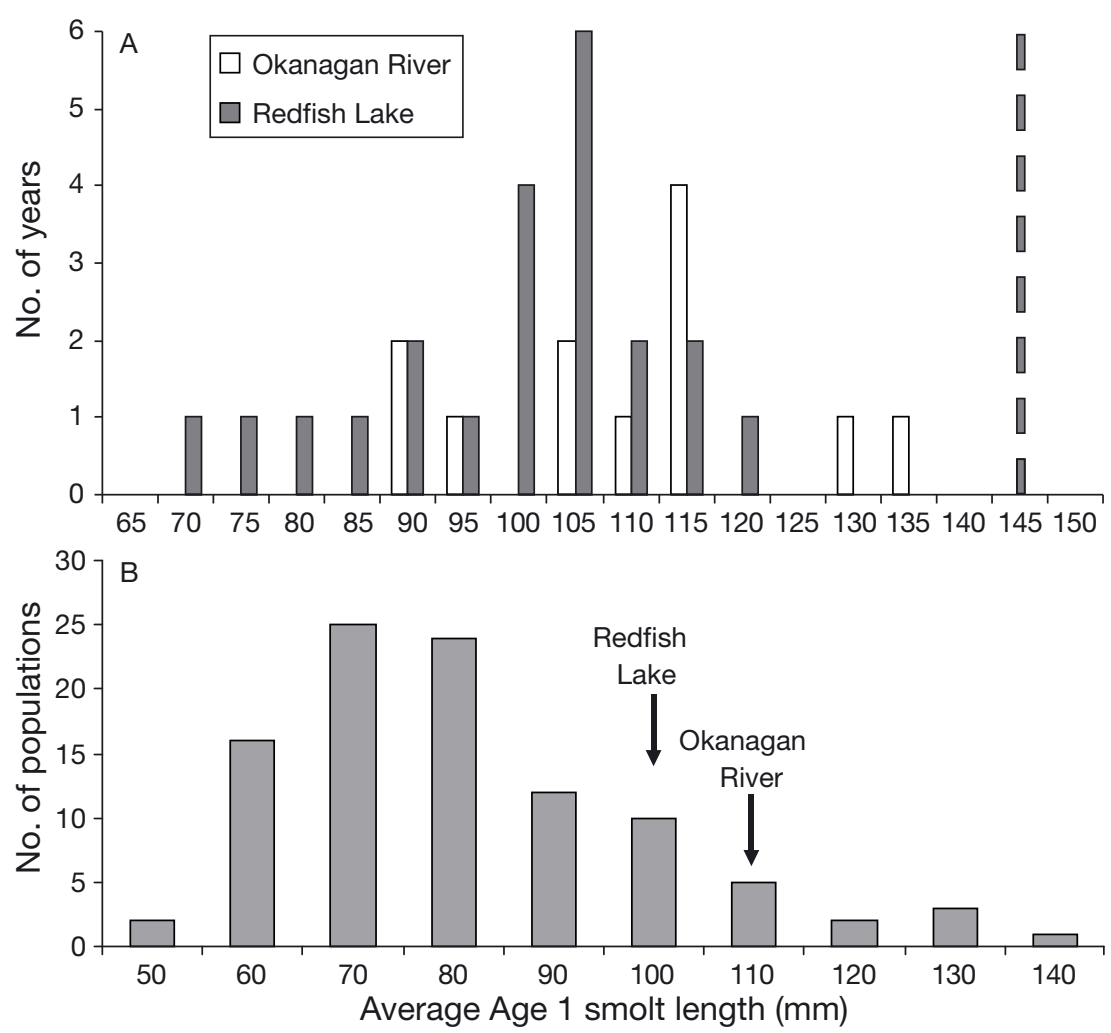

Fig. 3. Oncorhynchus nerka. (A) Histogram of average wild sockeye salmon Age 1 smolt lengths from Redfish Lake $(\mathrm{n}=22 \mathrm{yr})$ and Okanagan River $(\mathrm{n}=12 \mathrm{yr})$ between 1954 and 2007 (data from sources 2-4, 19-22, 23-29, and 31-35 in Table $\mathrm{S} 1$ in the supplement at www.int-res.com/articles/suppl/n013p051_supp.pdf). Dashed line represents the average smolt length observed in the laboratory (146 mm for both populations). No. of years: no. of years in which salmon were observed. (B) Average wild sockeye salmon smolt Age 1 lengths across their North American range (Okanagan River average length $=97.8 \mathrm{~mm}$, Redfish Lake average length $=107.8 \mathrm{~mm}$, overall mean across populations $=81.3 \mathrm{~mm}$; data compiled by T. Quinn)

Table 1. Oncorhynchus nerka. Percent of wild Okanagan River and Redfish Lake sockeye salmon maturing at different ocean ages over time

\begin{tabular}{|lccccc|}
\hline \multirow{2}{*}{ Population } & \multirow{2}{*}{ Years } & \multicolumn{3}{c}{ \% maturing at } & \\
\cline { 3 - 5 } & & Ocean age 1 & Ocean age 2 & Ocean age 3 \\
\hline Okanagan River & $1953-1974$ & 41 & 59 & 0 \\
Okanagan River & $1985-2008$ & 17 & 78 & 0.05 \\
Redfish Lake & $1953-1964$ & 4 & 88 & 0.08 \\
\hline
\end{tabular}

\section{Laboratory experiment}

Smolt age and size

In captivity, all Redfish Lake and Okanagan River sockeye salmon demonstrated a significant increase in gill $\mathrm{Na}+/ \mathrm{K}+-\mathrm{ATPase}$ activity during their second spring (2006), indicating that all fish experienced the parr to smolt transformation as yearlings. Specifically, enzyme activity rose from basal levels of 1.98 (Redfish Lake) and 1.89 (Okanagan River) $\mu$ moles of ADP $\mathrm{mg}^{-1}$ protein $\mathrm{h}^{-1}$ in February to peak levels of 6.8 and 10.5 umoles of ADP $\mathrm{mg}^{-1}$ protein $\mathrm{h}^{-1}$ in May 2006 for Redfish Lake and Okanagan River sockeye salmon, respectively. Captively reared smolts from both populations were larger than those seen in the wild, as the rations were designed to produce large, similarly-sized smolts.

No differences in growth rate or mean length of captive fish were found between the 2 populations at any of the 7 sampling events before and through smolt transformation (2- tailed 2-sample Student's $t$-test when data were normally distributed or MWW tests when they were not, all $\mathrm{p}>0.05$ ). Weights were not different between populations at 6 of the 7 sampling events (2- tailed 2-sample Student's $t$ test or MWW tests, $p>0.05$ for 6 events and 0.009 for 1 event). Tank effects were minimal; very few differences in mean lengths or weights of fish of a given population among tanks were detected during the sampling events. By June 2006, the final sampling event for smolts, all fish in both populations had smolted, both populations averaged $146 \mathrm{~mm}$ long, and Redfish Lake

Redfish Lake sockeye matured after $2 \mathrm{yr}$ at sea and spawned at Age 4 or 5, and almost no adults from this population matured after $1 \mathrm{yr}$ in the ocean (Table 1; Bjornn et al. 1968). Wild Okanagan River adult sockeye were significantly shorter at maturation than Redfish Lake fish (average length of ocean age-2 Okanagan $=496 \pm 20 \mathrm{~mm}$ across $27 \mathrm{yr}$ between 1957 and 2008 versus average length of mostly ocean age-2 Redfish Lake $=544 \pm 33 \mathrm{~mm}$ across 28 yr from 1953 to 2008, data from sources $1,3-18,30$, and $36-37$ in Table S1; Fig. $4 ; W=80, \mathrm{p}<0.0001$ for an MWW test). smolts were, on average, $1.5 \mathrm{~g}$ heavier than Okanagan smolts (35.0 g versus $33.5 \mathrm{~g}$, respectively).

\section{Age and size at maturation}

The age at maturation patterns of captive fish differed from those of wild fish. While $68 \%$ of captive Okanagan River sockeye matured 1 yr after smolting (as 3-yr-olds), $98 \%$ of captive Redfish Lake sockeye salmon matured at this age $\left(\chi^{2}=71.31, \mathrm{df}=1, \mathrm{p}<0.001\right.$ 


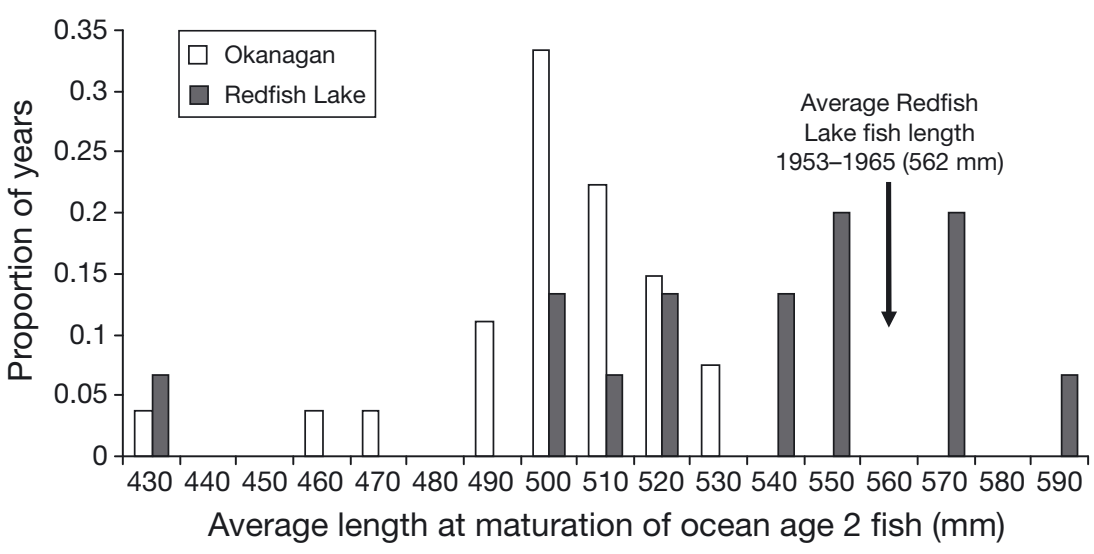

Fig. 4. Oncorhynchus nerka. Individual years' average lengths, between 1953 and 2008, of maturing ocean age 2 wild Okanagan River ( $\mathrm{n}=27$ years) and Redfish Lake ( $\mathrm{n}=28$ years) adult sockeye salmon (data from sources $1,3-18$, 30 , and 36-37 in Table S1). Whereas year-specific average length values were available for most years, the lengths of all Redfish Lake fish sampled between 1953 and 1965 were given as 1 average value (Bjornn et al. 1968); this value is represented by the arrow and was incorporated into the overall average

\section{DISCUSSION}

Data collected between 1946 and 2008 showed that wild Okanagan River and Redfish Lake sockeye salmon differed consistently in age and size at smolt transformation and maturation. Wild Redfish Lake smolts are, on average, smaller and smolt more frequently at older ages than Okanagan River sockeye. This is consistent with the colder conditions and lower productivity in the higher elevation Redfish Lake. Okanagan River sockeye salmon adults have matured at younger ages, often after only $1 \mathrm{yr}$ in the ocean, and at smaller sizes than Redfish Lake adults. Maturation of Okanagan River fish as 3-yr-olds is consistent with the very large size of their smolts. Similar results have been observed for sockeye salmon in nearby

for a chi-squared test comparing age at maturation between the populations). Mature Age 3 captive adults from the 2 populations did not differ significantly in length (Okanagan $=456 \mathrm{~mm}$ and Redfish Lake $=$ $460 \mathrm{~mm}$; WMM test due to non-normal distribution of data, $W=32484, \mathrm{p}=0.42$ ) or weight (Okanagan = $1135 \mathrm{~g}$ and Redfish Lake $=1163 \mathrm{~g}$; WMM test, $W=$ $31559, \mathrm{p}=0.18$ ). Most maturing fish from both populations were between 440 and $480 \mathrm{~mm}$ long and between 1000 and $1400 \mathrm{~g}$ in mass. Calculated $L_{\mathrm{p} 50}$ values of the PMRNs, $415 \mathrm{~mm}$ for Okanagan River fish and $405 \mathrm{~mm}$ for Redfish Lake sockeye salmon, were significantly different (Fig. 5A,B; likelihood ratio test, $D=9.69, \mathrm{df}=2, \mathrm{p}=0.008$ ).

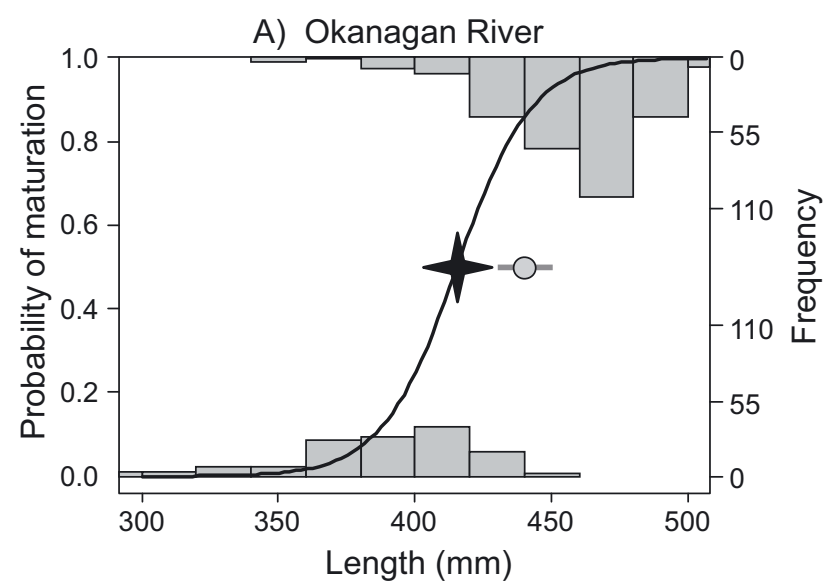

Lake Washington, where smolts are also very large, and Age-3 adults are also found (Hendry \& Quinn 1997). Under controlled laboratory conditions, age and size at smolt transformation and maturation differed considerably from those shown in the wild. All individuals from both populations smolted at Age 1 and at similar sizes in captivity. The relationship between faster growth and greater tendency to undergo smolt transformation at a younger age is widely seen in salmonids (e.g. Hutchings \& Jones 1998, Quinn et al. 2009), so this result was not unexpected. The accelerated juvenile growth in captivity may have contributed to all individuals reaching a size or growth rate threshold needed to trigger smolt transformation at Age 1.

Fig. 5. Oncorhynchus nerka. Lengths of immature (bottom) and maturing (top) captively reared (A) Okanagan River and (B) Redfish Lake sockeye salmon with fitted logistic curves describing the probability of maturation by length. The length at which the probability of maturation is $50 \%\left(L_{\mathrm{p} 50}\right)$ is represented by the star in each panel. The grey circle and line represent the average length and SD of wild smolt and ocean age 1 Okanagan River $(400 \pm 10 \mathrm{~mm})$ and Redfish Lake $(451 \pm 12.5 \mathrm{~mm})$ sockeye salmon (data from sources $3,6-13,15-18,30$, and 36 in Table S1) 
The controlled laboratory rearing also appeared to strongly affect adult maturation; almost all Redfish Lake sockeye salmon matured 1 yr after smolting, as did twothirds of Okanagan River fish. Thus, favorable environmental conditions in captivity acted on smolt size and overall growth, which contributed to the observed younger age and larger size at maturation in these sockeye salmon populations. Abundant evidence suggests a negative relationship between smolt size and adult age at maturity in wild (e.g. Hyatt \& Stockner 1985, Quinn et al. 2009) and hatchery populations (Quinn et al. 2004, Vøllestad et al. 2004). In addition, limited data from the Redfish Lake hatchery program are consistent with this reduction in age at maturity with increased smolt size. In 9 of the last 12 yr with data, hatchery smolts were between 20 and $50 \mathrm{~g}$ in weight, and ocean age 1 adults were never recorded. In the 3 yr when hatchery smolts exceeded $50 \mathrm{~g}(1998,2006$, and 2007), ocean age 1 adults were seen (D. Baker, IDFG, unpubl. data). Reproductive benefits (e.g. fecundity) generally increase with fish size, but these benefits must be balanced against the risks of mortality associated with an additional year at sea, so the largest individuals of a cohort generally mature at an earlier age than smaller ones (Quinn et al. 2009 and references therein). Thus it was not surprising, given their large size as smolts, that most captive Okanagan River and Redfish Lake sockeye salmon matured 1 yr after smolt transformation. However, it was at first surprising that a higher percentage of the captive Redfish Lake than Okanagan River fish matured 1 yr after smolting.

Calculated $L_{\mathrm{p} 50}$ values from the PMRNs indicated that the maturation size threshold of the Redfish Lake sockeye salmon was lower than that of the Okanagan River fish under the experimental conditions. These differences can be interpreted in light of the different environments in which the populations evolved. Juvenile Redfish Lake sockeye salmon rear in a high elevation, cool, and unproductive lake, and are smaller as smolts than the Okanagan River population. In captivity, the larger than normal size at smolt transformation of the Redfish Lake sockeye salmon may have triggered maturation at a younger age than typically occurs in the wild. The size difference between captive and wild smolts was not as great for the Okanagan River population as for the Redfish Lake population, and the increase in proportion of Age 3 adults (relative to wild fish) was also not as great for Okanagan River fish as for Redfish Lake fish. These differences in maturation threshold between these 2 populations, in addition to the differences in age and size at maturation of wild fish, are consistent with the presence of local adaptation in the populations. PMRNs have been helpful in other studies to understand and evaluate adaptive responses and spatial and temporal variation of maturation schedules (e.g. Olsen et al. 2008, Wang et al. 2008, Vainikka et al. 2009). Olsen et al. (2008) found that spatial diversity in maturation schedules, suggested by different PMRNs, corresponded to genetic differences in coastal Atlantic cod Gadus morhua. Wang et al. (2008) used PMRNs to show spatial and temporal variation in adaptive responses in maturation schedules for lake whitefish Coregonus clupeaformis. Finally, Vainikka et al. (2009) evaluated spatial variation in maturation patterns compensating for environmental gradients in Baltic herring Clupea harengus membras using PMRNs.

Our results were inconsistent with the null hypothesis that age and size at maturation were similar between the 2 sockeye salmon populations in captivity. They were most consistent with the second alternative hypothesis, that age and size at maturation patterns in the laboratory would be reversed from those seen in the wild. This latter pattern, due to interactions between environmental and genetic influences, may be an example of countergradient variation in the Redfish Lake and Okanagan River sockeye salmon maturation size threshold. If maturation thresholds are lower for Redfish Lake than Okanagan River fish, then the similar growth rates in the laboratory would result in higher proportions of Redfish Lake salmon maturing at an early age. In contrast, under the natural conditions (slower growth for the Redfish Lake fish), a lower proportion would mature at an early age. Both variation in maturation rate and threshold under experimental conditions and differences in maturation age and size in wild fish suggest genetic influences on the age and size at maturation patterns.

Factors such as different smolt weights and unequal variances in length and weight of maturing fish between the captive populations may have influenced our results, and the extrapolation used to calculate length of immature and maturing fish on a common date may have increased the uncertainty of the estimation of the PMRN $L_{\mathrm{p} 50}$ values. Still, our results are consistent with other indications of population-specific variation in life history traits in salmonids (Taylor 1991, Wood 1995). Research on the evolution of life history traits in newly established Chinook salmon Oncorhynchus tshawytscha populations in New Zealand indicated that populations diverged most strongly in growth rates rather than maturation probability (Kinnison et al. in press). Thus, the evolution of maturation thresholds as an adaptation to local conditions may occur more slowly than differences in growth. Future work exposing the captive sockeye salmon used in our study to a variety of temperatures and rations, and thus growth rates, would allow for a better understanding of complete PMRNs. This would also enable a better determination of maturation thresholds and genetic differences between the populations. 
Life history data from wild Okanagan River and Redfish Lake sockeye salmon are limited due to lack of sampling in many past years and to the recent scarcity of Redfish Lake sockeye salmon. Hatchery practices, introduction of different stocks, and other factors may have affected life history patterns of these populations over time. The Redfish Lake sockeye salmon population declined to a small number of individuals before the captive rearing program began (Peterson et al. 2008), so the population may be genetically bottlenecked. Thus, a reduced range of life history traits may be expressed in the current population if genes influencing such traits were lost with the population's decline. Still, salmonid populations can retain significant levels of genetic variation even after declining in abundance (e.g. Neville et al. 2007) and differences in age and size at smolt transformation and maturity between the wild Redfish Lake and Okanagan River sockeye salmon have persisted over time. We believe that the available data are broadly representative of the populations' patterns, though we recognize the inter-annual variation and effects of multiple factors on these traits.

Ideally, the ancestors of the fish used in our study would have been the same age, come from many different families within a balanced study design, been taken directly from their wild settings and been free of hatchery influence, and been maintained for several generations in a common environment (Conover \& Schultz 1995). We cannot rule out a genetic influence on age at maturity stemming from that of the parents of the fish in this study or maternal influences resulting from the parents of these fish being reared at separate locations. Thus, the findings of the laboratory experiment portion of this study could suggest hatchery adaptation rather than supporting the finding of local adaptation. However, the Redfish Lake sockeye salmon captive breeding program has been managed with the specific goal of preventing domestication selection (Kozfkay et al. 2008). While genetic erosion in supportive breeding programs can result from unbalanced sex ratios, inadequate strategies of crossing fish, and decreases in population sizes (Wang \& Ryman 2001, Machado-Schiaffino et al. 2007), the Redfish Lake sockeye salmon captive breeding program has specifically sought to develop strategies that minimize domestication selection, inbreeding, and loss of genetic diversity while increasing effective population size (Kozfkay et al. 2008). While this breeding program produces almost exclusively Age 3 adults, likely because the warmer water temperature in which the fish are reared $\left(10^{\circ} \mathrm{C}\right)$ and the feeding regime allow rapid growth (Frost et al. 2008, C. McAuley, NOAA Fisheries, pers. comm.), when the offspring of these fish are released into the wild they have matured mostly as 4or 5-yr-olds (D. Baker, IDFG, unpubl. data).
Effective conservation and management requires the identification of biologically relevant units, and thus differences among populations within species (Waples 1991, Neville et al. 2007), but this is just the first step. Life history diversity among populations within a given stock, such as Columbia River sockeye salmon, should be maintained to allow continued productivity and ecosystem services (Greene et al. 2010, Schindler et al. 2010). Selective fishing regimes on mixed stocks can overharvest certain populations, which may result in a loss of some local adaptation (Walters \& Martell 2004). Shifts in environmental conditions, such as climate change, are likely to affect smolt size and maturation patterns, potentially strengthening local adaptation or homogenizing populations. Finally, introduction of individuals to a new habitat, supplementation of current populations, or population transplantations will be more successful when life history trait variability is considered. Okanagan River and Redfish Lake sockeye salmon displayed different maturation rates and size thresholds in the laboratory and differed in age at maturation in the wild. As these populations experience complex combinations of changes in growing conditions at sea, artificial propagation (see http://tdn.com/news/article_ 9beb8b95-5955-551e-885b-a4094a100193.html), and exposure to fishing, the effects on size and age at maturity may reflect the underlying connections between genetic and environmental controls. The persistence of the populations may depend on the outcome of these interactions.

Acknowledgements. We thank J. Fryer of the Columbia River Inter-tribal Fish Commission; H. Wright of the Okanagan Nation Alliance; M. Stockwell of DFO; and J. Heindel, D. Baker, and M. Peterson of the Idaho Department of Fish and Game for providing data on wild fish. Funding for the controlled rearing experiment was provided by a contract from the Bonneville Power Administration to A.H.D. We gratefully acknowledge C. McAuley of NOAA Fisheries and A. Cleveland of the Confederated Tribes of the Colville Indian Reservation for providing salmon; D. Rose for help with fish husbandry; and D. May, M. Havey, L. Felli, K. Wood, and J. Athos for help with sampling fish. Anonymous reviewers provided helpful feedback that improved the manuscript considerably. H.B. Rich Jr. created the map in Fig. 1 and A.E. Punt provided helpful comments on the manuscript. N.W.K. was supported by the School of Aquatic and Fishery Sciences at the University of Washington, the Gordon and Betty Moore Foundation, and the National Science Foundation's BioComplexity Program.

\section{LITERATURE CITED}

Arendt JD, Wilson DS (1999) Countergradient selection for rapid growth in pumpkinseed sunfish: disentangling ecological and evolutionary effects. Ecology 80:2793-2798

Ayllon F, Martinez JL, Garcia-Vazquez E (2006) Loss of regional population structure in Atlantic salmon, Salmo salar L., following stocking. ICES J Mar Sci 63:1269-1273 
Beacham TD, Murray CB (1987) Adaptive variation in body size, age, morphology, egg size, and developmental biology of chum salmon (Oncorhynchus keta) in British Columbia. Can J Fish Aquat Sci 44:244-261

Beechie T, Buhle E, Ruckelshaus MH, Fullerton A, Holsinger L (2006) Hydrologic regime and the conservation of salmon life history diversity. Biol Conserv 130:560-572

Bjornn TC, Craddock DR, Corley DR (1968) Migration and survival of Redfish Lake, Idaho, sockeye salmon, Oncorhynchus nerka. Trans Am Fish Soc 97:360-373

Burgner RL (1991) Life history of sockeye salmon (Oncorhynchus nerka). In: Groot C, Margolis L (eds) Pacific salmon life histories. UBC Press, Vancouver, BC, p 1-117

- Carlson SM, Seamons TR (2008) A review of quantitative genetic components of fitness in salmonids: implications for adaptation to future change. Evol Appl 1:222-238

Conover DO, Present TMC (1990) Countergradient variation in growth rate: compensation for length of the growing season among Atlantic silversides from different latitudes. Oecologia 83:316-324

Conover DO, Schultz ET (1995) Phenotypic similarity and the evolutionary significance of countergradient variation. Trends Ecol Evol 10:248-252

Conover DO, Brown JJ, Ehtisham A (1997) Countergradient variation in growth of young striped bass (Morone saxatilis) from different latitudes. Can J Fish Aquat Sci 54: 2401-2409

Craig JK, Foote CJ (2001) Countergradient variation and secondary sexual color: phenotypic convergence promotes genetic divergence in carotenoid use between sympatric anadromous and nonanadromous morphs of sockeye salmon (Oncorhynchus nerka). Evolution 55:380-391

Crozier LG, Hendry AP, Lawson PW, Quinn TP and others (2008) Potential responses to climate change in organisms with complex life histories: evolution and plasticity in Pacific salmon. Evol Appl 1:252-270

Dieckmann U, Heino M (2007) Probabilistic maturation reaction norms: their history, strengths, and limitations. Mar Ecol Prog Ser 335:253-269

Dittman AH, May D, Havey M, Felli L (2009) Determining critical imprinting periods for sockeye salmon. In: Berejikian BA (ed) Project 1993-056-00 progress report (performance period: 1 June 2008 through 31 May 2009): research on captive broodstock programs for Pacific salmon-annual report. US Department of Energy, Bonneville Power Administration, Portland, OR, p 23-44

Frost DW, McAuley WC, Maynard DJ, Wastel MR, Kluver B, Flagg TA (2008) Redfish Lake sockeye salmon captive broodstock rearing and research, 2007. US Department of Energy, Bonneville Power Administration, Portland, OR

Fryer JK (1995) Columbia basin sockeye salmon: causes of their past decline, factors contributing to their present low abundance, and the future outlook. PhD dissertation, University of Washington, Seattle, WA

- Garcia de Leaniz C, Fleming IA, Einum S, Verspoor E and others (2007) A critical review of adaptive genetic variation in Atlantic salmon: implications for conservation. Biol Rev Camb Philos Soc 82:173-211

Greene CM, Hall JE, Guilbault KR, Quinn TP (2010) Improved viability of populations with diverse life-history portfolios. Biol Lett 6:382-386

Grether GF, Cummings ME, Hudon J (2005) Countergradient variation in the sexual coloration of guppies (Poecilia reticulata): drosopterin synthesis balances carotenoid availability. Evolution 59:175-188

Gustafson RG, Wainwright TC, Winans GA, Waknitz FW, Parker LT, Waples RS (1997) Status review of sockeye salmon from Washington and Oregon. Report No. NMFSNWFSC-33. National Oceanic and Atmospheric Administration, Seattle, WA

> Hankin DG, Nicholas JW, Downey TW (1993) Evidence for inheritance of age of maturity in chinook salmon (Oncorhynchus tshawytscha). Can J Fish Aquat Sci 50:347-358

Hard JJ (2004) Evolution of chinook salmon life history under size-selective harvest. In: Hendry AP, Stearns SC (eds) Evolution illuminated: salmon and their relatives. Oxford University Press, Oxford, p 316-337

> Heino M, Dieckmann U, Godø OR (2002) Measuring probabilistic reaction norms for age and size at maturation. Evolution 56:669-678

> Hendry AP, Quinn TP (1997) Variation in adult life history and morphology among Lake Washington sockeye salmon (Oncorhynchus nerka) populations in relation to habitat features and ancestral affinities. Can J Fish Aquat Sci 54: $75-84$

Holtby LB (1988) Effects of logging on stream temperatures in Carnation Creek, British Columbia, and associated impacts on the coho salmon (Oncorhynchus kisutch). Can J Fish Aquat Sci 45:502-515

> Hsieh CH, Reiss CS, Hunter JR, Beddington JR, May RM, Sugihara G (2006) Fishing elevates variability in the abundance of exploited species. Nature 443:859-862

Hutchings JA, Jones MEB (1998) Life history variation and growth rate thresholds for maturity in Atlantic salmon, Salmo salar. Can J Fish Aquat Sci 55:22-47

> Hyatt KD, Stockner JG (1985) Response of sockeye salmon (Oncorhynchus nerka) to fertilization of British Columbia coastal lakes. Can J Fish Aquat Sci 42:320-331

> Kendall NW, Hard JJ, Quinn TP (2009) Quantifying six decades of fishery selection for size and age at maturity in sockeye salmon. Evol Appl 2:523-536

Kinnison MT, Quinn TP, Unwin MJ (in press) Correlated contemporary evolution of life history traits in New Zealand Chinook salmon, Oncorhynchus tshawytscha. Heredity

Koellner T, Schmitz OJ (2006) Biodiversity, ecosystem function, and investment risk. Bioscience 56:977-985

Kozfkay CC, Campbell MR, Heindel JA, Baker DJ, Kline P, Powell MS, Flagg T (2008) A genetic evaluation of relatedness for broodstock management of captive, endangered Snake River sockeye salmon, Oncorhynchus nerka. Conserv Genet 9:1421-1430

> Larsen DA, Beckman BR, Cooper KA, Barrett D, Johnston M, Swanson P, Dickhoff WW (2004) Assessment of high rates of precocious male maturation in a spring Chinook salmon supplementation hatchery program. Trans Am Fish Soc 133:98-120

> Laugen AT, Laurila A, Rasanen K, Merila J (2003) Latitudinal countergradient variation in the common frog (Rana temporaria) developmental rates - evidence for local adaptation. J Evol Biol 16:996-1005

> Machado-Schiaffino G, Dopico E, Garcia-Vazquez E (2007) Genetic variation losses in Atlantic salmon stocks created for supportive breeding. Aquaculture 264:59-65

> Marcil J, Swain DP, Hutchings JA (2006) Countergradient variation in body shape between two populations of Atlantic cod (Gadus morhua). Proc R Soc Lond B Biol Sci 273:217-223

McCormick SD (1993) Methods for nonlethal gill biopsy and measurement of $\mathrm{Na}+, \mathrm{K}+$-ATPase activity. Can J Fish Aquat Sci 50:656-658

> McLean JE, Bentzen P, Quinn TP (2005) Nonrandom, sizeand timing-biased breeding in a hatchery population of steelhead trout. Conserv Biol 19:446-454

$>$ Neville H, Isaak D, Thurow R, Dunham J, Rieman B (2007) Microsatellite variation reveals weak genetic structure 
and retention of genetic variability in threatened Chinook salmon (Oncorhynchus tshawytscha) within a Snake River watershed. Conserv Genet 8:133-147

Olsen EM, Knutsen H, Gjøsaeter J, Jorde PE, Knutsen JA, Stenseth NC (2008) Small-scale biocomplexity in coastal Atlantic cod supporting a Darwinian perspective on fisheries management. Evol Appl 1:524-533

Peterson M, Plaster K, Redfield L, Heindel J, Kline P (2008) Snake River sockeye salmon captive broodstock program; research element: annual report 2007. Idaho Department of Fish and Game, Boise, ID

Pyper BJ, Peterman RM, Lapointe MF, Walters CJ (1999) Patterns of covariance in length and age at maturity of British Columbia and Alaska sockeye salmon (Oncorhynchus nerka) stocks. Can J Fish Aquat Sci 56:1046-1057

Quinn TP, Vøllestad LA, Peterson J, Gallucci V (2004) Influences of freshwater and marine growth on the egg sizeegg number tradeoff in Coho and Chinook salmon. Trans Am Fish Soc 133:55-65

Quinn TP, Doctor K, Kendall N, Rich HB Jr (2009) Anadromy and the life history of salmonid fishes: nature, nurture, and the hand of man. In: Haro AJ, Smith KL, Rulifson RA, Moffitt CM and others (eds) Challenges for diadromous fishes in a dynamic global environment. Am Fish Soc Symp 69, Bethesda, MD, p 23-42

Randall RG, Thorpe JE, Gibson RJ, Reddin DG (1986) Biological factors affecting age at maturity in Atlantic salmon (Salmo salar). Publ Spec Can Sci Halieut Aquat 89:90-96

Randall JK, Healey MC, Dempson JB (1987) Variability in length of freshwater residence of salmon, trout, and char. Am Fish Soc Symp 1:27-41

Ricker WE (1972) Heritability and environmental factors affecting certain salmonid populations. In: Simon RC, Larkin PA (eds) The stock concept in Pacific salmon. H.R. McMillan lectures in fisheries. University of British Columbia, Vancouver, BC, p 27-160

Roni P, Quinn TP (1995) Geographic variation in size and age of North American chinook salmon. N Am J Fish Manag 15:325-345

Schindler DE, Hilborn R, Chasco B, Boatright CP, Quinn TP, Rogers LA, Webster MS (2010) Population diversity and the portfolio effect in an exploited species. Nature 465:609-612

Editorial responsibility: Steven Cooke, Ottawa, Ontario, Canada
Taylor EB (1991) A review of local adaptation in Salmonidae, with particular reference to Pacific and Atlantic salmon. Aquaculture 98:185-207

Thorpe JE (1986) Age at first maturity in Atlantic salmon, Salmo salar: freshwater period influences and conflicts with smolting. Publ Spec Can Sci Halieut Aquat 89:7-14

Thorpe JE (1987) Smolting versus residency: developmental conflict in salmonids. Am Fish Soc Symp 1:244-252

> Tipping JM (1991) Heritability of age at maturity in steelhead. N Am J Fish Manag 11:105-108

> Vainikka A, Mollet F, Casini M, Gårdmark A (2009) Spatial variation in growth, condition, and maturation reaction norms of the Baltic herring Clupea harengus membras. Mar Ecol Prog Ser 383:285-294

> Venturelli PA, Shuter BJ, Murphy CA (2009) Evidence for harvest-induced maternal influences on the reproductive rates of fish populations. Proc R Soc Lond B Biol Sci 276: 919-924

Vøllestad LA, Peterson J, Quinn TP (2004) Effects of freshwater and marine growth rates on early maturity in male coho and Chinook salmon. Trans Am Fish Soc 133: 495-503

Walters CJ, Martell SJD (2004) Fisheries ecology and management. Princeton University Press, Princeton, NJ

> Wang J, Ryman N (2001) Genetic effects of multiple generations of supportive breeding. Conserv Biol 15: 1619-1631

Wang HY, Hook TO, Ebener MP, Mohr LC, Schneeberger PJ (2008) Spatial and temporal variation of maturation schedules of lake whitefish (Coregonus clupeaformis) in the Great Lakes. Can J Fish Aquat Sci 65:2157-2169

Waples RS (1991) Pacific salmon, Oncorhynchus spp., and the definition of 'species' under the Endangered Species Act. Mar Fish Rev 53:11-22

Waples RS, Gustafson RG, Weitkamp LA, Myers JM and others (2001) Characterizing diversity in salmon from the Pacific Northwest. J Fish Biol 59:1-41

Wood CC (1995) Life history variation and population structure in sockeye salmon. Am Fish Soc Symp 17:195-216

Zaugg WS (1982) A simplified preparation for adenosinetriphosphatase determination in gill tissue. Can J Fish Aquat Sci 39:215-217

Submitted: August 20, 2010; Accepted: October 24, 2010 Proofs received from author(s): November 23, 2010 